\title{
Stranded Research? Leading Finance Journals are Silent on Climate Change
}

\author{
Ivan Diaz-Rainey*, \\ Department of Accountancy and Finance \& the Otago Energy Research Centre (OERC), University of Otago, \\ PO Box 56, Dunedin 9054, New Zealand. \\ Becky Robertson \\ Tyndall Centre for Climate Change Research, School of Environmental Sciences, University of East Anglia, \\ Norwich NR4 7TJ, UK. \\ and \\ Charlie Wilson \\ Tyndall Centre for Climate Change Research, School of Environmental Sciences, University of East Anglia, \\ Norwich NR4 7TJ, UK.
}

\begin{abstract}
Finance research has shaped the modern financial system, influencing investors and market participants directly through research findings and indirectly through teaching and training programmes. Climate change presents major risks to the global financial system as well as new opportunities for investors. Is climate finance an important topic in finance research? We systematically analyse the content of 20,725 articles published in the leading 21 finance journals between January 1998 and June 2015. We find only 12 articles $(0.06 \%)$ are related in some way to climate finance. The three elite finance journals (Journal of Finance, Journal of Financial Economics, and Review of Financial Studies) did not publish a single article related to climate finance over the 16.5 year period. We repeat our analysis across a sample of 29 elite business journals spanning accounting, economics, management, marketing and operations research, as well as finance. We find a similar dearth of published climate finance research. We consider four possible explanations for this failure of top finance and business journals to engage with climate finance as a research topic. These include methodological constraints and editorial policies. We conclude by arguing why it is critical for climate-related research to be given greater attention and prominence in finance journals.
\end{abstract}

Key words: Climate Change; Climate Finance; Climate Research; Environmental Finance; Finance Research; Finance Curriculums

Acknowledgments: IDR acknowledges University of Otago research leave funding which made this research possible. CW \& BR acknowledge the support of the Tyndall Centre for Climate Change Research. Useful suggestions were received during a related presentation by IDR at the Smith School of Enterprise and the Environment, University of Oxford (June 2016).

* Corresponding author: Tel. +64 3 479 8117; Email: ivan.diaz-rainey@otago.ac.nz 


\section{Introduction}

Climate change presents both major risks to the global financial system and an opportunity for investors. Climate finance has become a defining topic in policy and practice, with major current debates around stranded fossil fuel assets, divestment from carbonintensive stocks, the direct (physical) impact of climate change on assets, carbon markets, green investing and development finance, risk management strategies including climate insurance, and broader financial stability risks (Dietz et al. 2016; Pauw et al. 2016; Batten et al. 2016; Griffin et al. 2015; Van Renssen 2014; Leaton 2011). There is no accepted taxonomy of climate finance, reflecting its emergent nature. However, common distinctions are made between mitigation or adaptation climate finance, and between public or private climate finance (Pauw et al. 2016).

In this paper we explore whether climate finance is an important topic in finance research. Finance research is principally concerned with the functioning of private finance and so can help advance understanding of the interplay between financial markets and investors on the one hand and climate change on the other - be it related to mitigation or adaptation.

All the 'core' areas of finance research - assert pricing, corporate finance and investments - are relevant to climate change. As an illustrative example, the 'asset pricing' branch of finance research, which takes the perspective of traders, could help uncover to what degree investors are pricing carbon risk into asset values and is thus relevant to contemporary debates on stranded assets (Ansar et al. 2013; Carbon Tracker Initiative 2013; Carbon Tracker Initiative 2015; Dietz et al. 2016; Griffin et al. 2015; Leaton 2011). 'Corporate finance' researchers, who take the perspective of companies, could help establish whether energy majors have the balance sheets to support the financing of a capital-intensive low carbon transition (Tulloch et al. 2017). 'Investments' researchers can evaluate if climate-friendly investment funds or bonds outperform their alternatives on a risk adjusted basis (Muñoz et al. 2014). Finance research in non-core areas can also contribute to understanding the relationships between private finance and climate change. Finance researchers concerned with 
insurance, risk management and financial institutions can help answer questions such as: what impact will rising sea levels have on real estate assets in large cities? what financial instruments can be used hedge carbon risk in investment portfolios? how exposed are banks to carbon risk, and banking systems more generally? (see Andersson et al. 2016; Batten et al. 2016; Carney 2015; Carbon Tracker Initiative 2013; de Jong and Nyugen 2016).

Leading climate change journals (including Nature Climate Change, Climatic Change, and Global Environmental Change) have clearly engaged with climate finance topics (Dietz et al. 2016; Patenaude 2011; Pauw et al. 2016; Van Renssen 2014). One would similarly expect leading finance journals to have engaged with climate change.

We use systematic content analysis to identify climate change-related and climate finance-related articles in a sample of over 20,000 articles during a 16.5 year period since the Kyoto Protocol introduced global carbon markets. We repeat this analysis for a further sample of over 31,000 articles in elite business journals during the same time period to determine if our results are specific to finance journals, or are more broadly representative of accounting, economics, management and other business journals. Content analysis is a widely used method for characterising published textual material through simple quantitative descriptors such as the frequency of occurrence of a defined set of 'codes'. The codes are linked to specific words, phrases or meanings of the textual content. Content analysis has recently been applied to large samples of journal articles to identify the disciplines, methods and concepts of energy-related social science (D'Agostino et al. 2011), the main findings of research on smart home technologies (Wilson et al. 2015), and the constituent types of low-carbon behaviour (Karlin et al. 2014).

We find a minimal level of engagement of finance and business journals with climate change-related and climate finance-related research, and we develop arguments as to why this might be the case. We conclude that this research gap is a major issue for advancing theory and practice in climate finance given the importance of finance research in shaping the modern financial system, in influencing investors and market participants, and in teaching the 
next generation of finance, investment, and business leaders. In so doing, we build on previous findings that business academics up to 2008 were slow to embrace climate change as a field of enquiry, although this research did not consider climate finance explicitly (Patenaude 2011; Goodall 2008).

\section{Method: Content analysis}

We identified leading finance journals ranked B and above (Currie and Pandher 2011) and elite business journals rated $4 *$ (ABS 2015). The samples comprised 21 finance journals (Table 1) and 29 elite business journals spanning accounting, economics, finance, management, marketing and operations research (Table 2). The top three finance journals were included in both samples (Journal of Finance, Journal of Financial Economics, Review of Financial Studies).

We used Scopus to search the content of these journals for articles on climate change (“climate” OR “global warming” OR “greenhouse” OR “carbon”). We searched titles, abstracts, and keywords in all article types. The search period covered a 16.5 year period from January 1998 to June 2015. The Kyoto Protocol was signed in December 1997 and provides a clear milestone in international climate policy including the formation of carbon markets. All the journals in our two samples were indexed by Scopus over the full search period with three exceptions (Review of Finance, Quantitative Finance and Journal of Financial Research). Coverage of these journals in Scopus began in 2004, 2003 and 2003 respectively. We used journals' own websites to search for articles in the period from January 1998 to these start dates to ensure no missing data.

A total of 36 articles in finance journals and 156 articles in elite business journals matched our search terms on climate change. We compiled metadata on all these articles and checked for spurious matches. Over half of all articles were spurious and not related to climate change (e.g., referring to a 'changing economic climate'). Two members of the research team (IDR, BR) independently carried out these checks, with inter-coder reliability 
(Krippendorff's Alpha) of .8854. A bootstrap procedure generates lower and upper 95\% CI of .7799 and .9600 , respectively. Any coding differences were checked by the third member of the research team $(\mathrm{CW})$ and resolved.

As shown in Figure 1, our final samples comprised 12 articles in finance journals (after rejecting 24 spurious matches) and 74 articles in elite business journals (after rejecting 82 spurious matches).

To determine whether the articles in these final samples were related to climate finance, we searched the compiled metadata using a set of financial terms ("financ*" OR “balance sheet” OR “asset” OR “valu*” OR “market” OR “trade” OR “trading” OR "securit*). A total of 12 (of 12) articles in leading finance journals and 25 (of 74) articles in elite business journals matched our climate finance-related search terms.

We coded each of these climate finance articles using a simple coding template which distinguishes key finance topics: (A) carbon markets; (B) value \& performance (including stranded assets, green funds); (C) risk and risk mitigation (including hedging and insurance); (D) investments and opportunities (including green bonds); (E) corporate strategies (including carbon accounting, socially responsible investment); (F) other (including carbon taxes, public climate finance). These topics were initially derived from an iterative process of reading the climate finance literature and reconciling this with established areas of finance research (for instance, commodity markets for topic A, risk management and insurance for topic C). For the coding, these topics were then refined and clearly defined so they were both discrete (nonoverlapping) and exhaustive. In each case we coded the main topic covered in the article.

To normalise our samples of climate change-related and climate finance-related articles, we used Scopus 'Compare Journals' statistics on the total number of articles published per journal. A total of 20,725 articles were published in our sample of 21 finance journals from January 1998 to June 2015 (see Table 1). A total of 31,351 articles were published in our sample of 29 elite business journals over the same time period (see Table 2). 
To account for more recent interest in climate finance particularly with respect to stranded assets, carbon bubbles, and divestment, we created subsamples of articles published during the period January 2012 to June 2015 (see Appendix, Table A1). The Carbon Tracker published its first report in November 2011 which was a milestone in raising general awareness of climate finance topics (Leaton 2011).

\section{[INSERT TABLE 1, TABLE 2, AND FIGURE 1 ABOUT HERE]}

\section{Results}

The results of our content analysis show a remarkable lack of engagement with climate change-related risks and opportunities by leading finance journals and elite business journals.

\section{Climate change-related research}

Table 1 shows that only $12(0.06 \%)$ of the 20,725 articles published in the 21 leading finance journals (Currie and Pandher 2011) since 1998 have related in some way to climate change. Furthermore, this almost complete lack of engagement with climate change as a research topic is not limited to finance. Table 2 similarly shows that only $74(0.24 \%)$ of the 31,351 articles published by $4 *$ 'elite' business journals (ABS 2015) over the same period addressed climate change-related issues (see also Figure 1). This research gap has scarcely improved in recent years as climate change has grown ever greater in relevance for finance. Over the period January 2012 to June 2015, only $0.10 \%$ (leading finance) and $0.49 \%$ (elite business) of articles published engaged with climate change (see Appendix, Table A1).

Among the elite business journals, we find that finance and marketing have not engaged with climate issues at all (see Table 2). We do find some limited engagement with climate change in elite journals from accounting, economics, management, operations research and 'other' business disciplines. Economics has engaged the most with climate topics, with all five elite journals having published at least one climate change-related paper and $0.5 \%$ of all publications addressing climate issues. However, it is noteworthy that of the 42 publication in economics, 36 come from one journal (America Economic Review). This 
highlights the importance of editorial policy in establishing journal norms (we return to this below).

The 21 leading finance journals have only published 12 climate change-related articles since 1998. Six of those were published since 2012 suggesting only a marginal increase in recent interest. Of the top ten journals only the Journal of Banking and Finance has published climate-related articles ( $\mathrm{n}=4)$. The Journal of Risk and Insurance is the only other journal to have published more than one article $(n=2)$ (see Table 1). Other than the Journal of Banking and Finance, the journals that have published climate change-related articles tended to be towards the bottom of the ranking list. The three elite finance journals (Journal of Finance, Journal of Financial Economics, and Review of Financial Studies) did not publish a single article related to climate change over the 16.5 year period. These findings are consistent with a recent review of 'what's hot' in finance research for the four leading finance journals over the period 2011 to 2015(see Bhattacharya et al. 2016). In the review there is no mention of climate, carbon or environmental finance.

\section{Climate finance-related research}

All 12 climate change-related articles in leading finance journals were coded as also being climate finance-related. In addition, 25 of 74 climate change-related articles in elite business journals were similarly coded as being climate finance-related. Figure 1 summarises the coding of these climate-finance related articles. Just under half of the 37 climate financerelated articles addressed carbon markets; an additional 14\% (the "other" category) mainly addressed carbon taxes. This leaves an almost complete absence of research on critically important issues of risk, valuation (including stranded assets) and investment opportunities related to climate change.

We conclude overall that there is a dearth of climate finance-related research in leading finance journals, and that this small number of contributions are disproportionately focused on carbon markets. Elite business journals, in particular in the accounting, economics and operations-research disciplines, have addressed climate finance-related topics to a very 
slightly greater extent ( $n=25$ vs. $n=12$ ) and while these address a broader set of issues, they also tend to be dominated by research on carbon markets and carbon taxes (see Table 2).

It is instructive to provide some context for our headline findings that $0.06 \%$ and $0.08 \%$ of all articles published from 1998 to 2015 in leading finance journals and elite business journals respectively are on climate finance-related research. In other words, what other topics are finance journals covering? Financial intermediation (including banking and related regulatory issues) and market microstructure (the study of how exchange occurs in financial markets) respectively accounted for $8 \%$ and $3.7 \%$ of articles published in the Journal of Finance between 2011 and 2015 (Bhattacharya et al. 2016). Research on financial intermediation has clearly grown in importance due to the global financial crisis, while market microstructure has become more prominent as electronic and high frequency trading have expanded across financial markets (see Diaz-Rainey et al. 2015). Both areas are distinct from the 'core' focus of finance research on asset pricing, corporate finance and investments which together accounted for $67 \%$ of research in the Journal of Finance over the same period (Bhattacharya et al. 2016).

\section{Discussion}

It is striking that finance research is so 'behind the climate curve' given that investment professionals (Van Renssen 2014) and financial regulators (Batten et al. 2016; FSB (2016) are strongly engaged with climate finance topics. We offer four possible explanations.

First, contemporary critiques of finance research suggest the discipline is isolated and increasingly distanced from practice or the reality of financial markets (Focardi and Fabozzi 2012; Keasey and Hudson 2007). For instance, Focardi and Fabozzi (2012 p p108-109) observe that "[a] true empirical science would revise its models so that they fit empirical data. Financial economics, however, takes the opposite approach and considers deviations from an idealized economic rationality to be anomalies of the true empirical price processes."

Similarly, Keasey and Hudson (2007) observe that finance researchers are reluctant to engage 
with practice, leading them to conclude that finance theory is "a house without windows". Accordingly, finance researchers seeking to publish in leading finance journals may be unaware of climate finance-related issues worthy of research attention. Among the leading finance journals, the two which are most practitioner-oriented have both published climate change-related articles. These are the Financial Analysts Journal (the Chartered Financial Analysts Institute's journal) and the Journal of Portfolio Management. Proximity to finance practice, and in particular to institutional investors, may help support engagement with climate change. Indeed, in 2016 (beyond our sample period) there have been two notable climate finance risk-related publications in the Financial Analysts Journal, namely Andersson et al. (2016) and de Jong and Nyugen (2016). The five authors involved in these two publications were practitioners or practitioners with ties to universities. None were 'conventional' finance academics.

Second, the finance discipline is essentially mono method (applied empiricism encased in rational agent theory) which is ill-suited to tackling forward-looking challenges arising from dynamic system change (Diaz-Rainey et al. 2015; Focardi and Fabozzi 2012; Keasey and Hudson 2007). This ‘limited domain’ problem (Diaz-Rainey et al. 2015) may explain why the climate finance-related research that has been published in leading finance journals has tended to focus on carbon markets as rich time-series datasets are readily available. If so, leading finance journals face fundamental epistemological challenges to remain relevant within the climate context.

Third, incentives within finance research publication may steer academics away from climate finance topics. There may be a perception amongst finance academics that climate finance-related topics do not provide the opportunities for high impact general theory development that 'core' research in asset pricing, corporate finance and investments allows for and which tends to dominate the leading finance journals (see earlier discussion, and Bhattacharya et al. 2016). Further, established research agendas and high teaching loads among finance academics in universities may create inertia. There is high demand to study 
finance and a limited pool of faculty talent, partly as a result of alternative career opportunities in the finance industry. Thus, rather than undertaking 'risky' research in new fields such as climate finance that leading editors may not be receptive to, busy finance researchers focus on incremental knowledge in clearly-recognised fields (Goodall 2008).

Fourth, and related to the previous points, researchers concerns that editors will not be responsive to climate finance topics may be well founded. This in turn may be related to leading finance professors (and journal editors) considering climate topics to be overly politicised (Goodall 2008). This effect may be accentuated by the US dominance of the finance discipline given the greater polarisation of views about, and scepticism towards, climate change in the US (Boussalis and Coan 2016; Painter and Ashe 2012; McCright and Dunlap 2011; Goodall 2008).

To explore this argument further, we identified the domiciles of the editorial teams of the 21 leading finance journals in our sample. We included co-editors, managing editors, and executive editors but excluded associated editors. We assigned 0 ('US') or 1 ('INT') to a dummy variable coding for editorial teams that were exclusively US-based or that included at least one non-US domiciled editor respectively (see Appendix, Table A2). Of the 12 journals coded as international ('INT'), most included a combination of US and non-US editors reflecting the US dominance of the discipline. Only two journals had no US based editors (Journal of Portfolio Management and Journal of Business Finance and Accounting). The phi coefficient of our dummy variable for all journals with at least one climate change-related publication was 0.481 and was significant at the $5 \%$ level. Leading finance journals publishing climate change-related research were categorised as having international editorial teams in all but one case (Journal of Futures Markets). We thus find a positive and statistically significant relationship between international editorial teams in leading finance journals and climate change-related research publications. This does not prove causality but does at least suggest exclusively US-based editorial teams may play a role in limiting climate changerelated research in leading finance journals. 


\section{Conclusion}

Respected field journals such as Energy Economics have engaged strongly with climate finance-related research (Griffin et al. 2015). There are many climate finance initiatives in academia, including the Oxford Stranded Assets Programme and the new Journal of Sustainable Finance \& Investment, although tellingly the former is based in a geography department and the latter is not ranked by the business journal ranking lists (ABS 2015). So to be clear, we are not arguing that researchers are not engaging with climate finance. Rather our concern is that elite business journals and leading finance journals have either not engaged at all or have only engaged in a very limited sense. This has important implications for policy and practice.

High profile publications in leading journals are important both for impact and academic career progression. Finance research is no different. Indeed rewards and prestige in finance research are particularly concentrated (Currie and Pandher 2011; Fishe 1998) in the three elite journals (Journal of Finance, Journal of Financial Economics, Review of Financial Studies). As noted earlier, none of these journals published a single article related to climate change over the 16.5 year period of our sample. Emphasising their importance to the pursuit of knowledge generally, the three leading finance journals are placed amongst the top one hundred journals in the world for all disciplines (according to 2016 SJR rankings).

Meaningful action to understand and address the impacts of climate change on the financial system requires the engagement of the best minds from academic finance and the attention of the leading journals that define the agendas in their fields. Leading finance journals should be publishing research on a range of climate finance-related topics including risks (e.g. speculative bubbles, financial contagion), valuation (e.g. carbon-risk disclosure requirements and related market impacts across numerous assets classes), opportunities (e.g. debt and equity market 'green' financing), and corporate strategies (e.g. divestments and used of hedging instruments). 
Until the top journals in finance and business signal that they are receptive to climate finance-related research, the best finance researchers are unlikely to engage. Since the articles from leading finance journals tend to underpin the finance curriculums of undergraduate and especially postgraduate qualifications in finance, perhaps the most prominent impact of the dearth of climate finance-related research in leading finance journals is that the next generation of finance practitioners may be underprepared to tackle climate change-related issues.

What might be done to alleviate this situation? First, there needs to be a better understanding of why leading finance journals have not engaged with climate change. We have offered several possible explanations above, but surveys or interviews of finance academics could provide substantiating evidence. Roundtables and seminars where senior finance academics (especially editors) are introduced to climate finance topics might also help. In this respect, professional and regulatory bodies engaged with climate finance issues could play an important role in bringing academics to the table. The Chartered Financial Analysts Institute and the Financial Stability Board (especially its Task Force on ClimateRelated Financial Disclosures) could be possible conduits. Finally, research funders can help by creating dedicated funding streams for climate finance issues that require interdisciplinary teams including finance researchers.

Through the data and analysis presented here we do not in any way seek to diminish finance research. We hope it can provide a stimulus to encourage leading finance researchers to engage with climate change and the many financial risks and opportunities it creates. That way climate finance topics can benefit from the knowledge, methods, and insights in finance research. This in turn will lead to better policymaking in what is surely one of the defining topics for finance and capital markets in the coming years and decades. 


\section{Compliance with Ethical Standards}

IDR, CW \& BR all declare that they do not have any competing financial interests related to this research. 


\section{Figures.}

Figure 1. Number of Climate Change-Related and Climate Finance-Related Articles in

Leading Finance Journals (top panel) and Elite Business Journals (bottom panel). Note:

Shaded areas are proportional to number of articles.

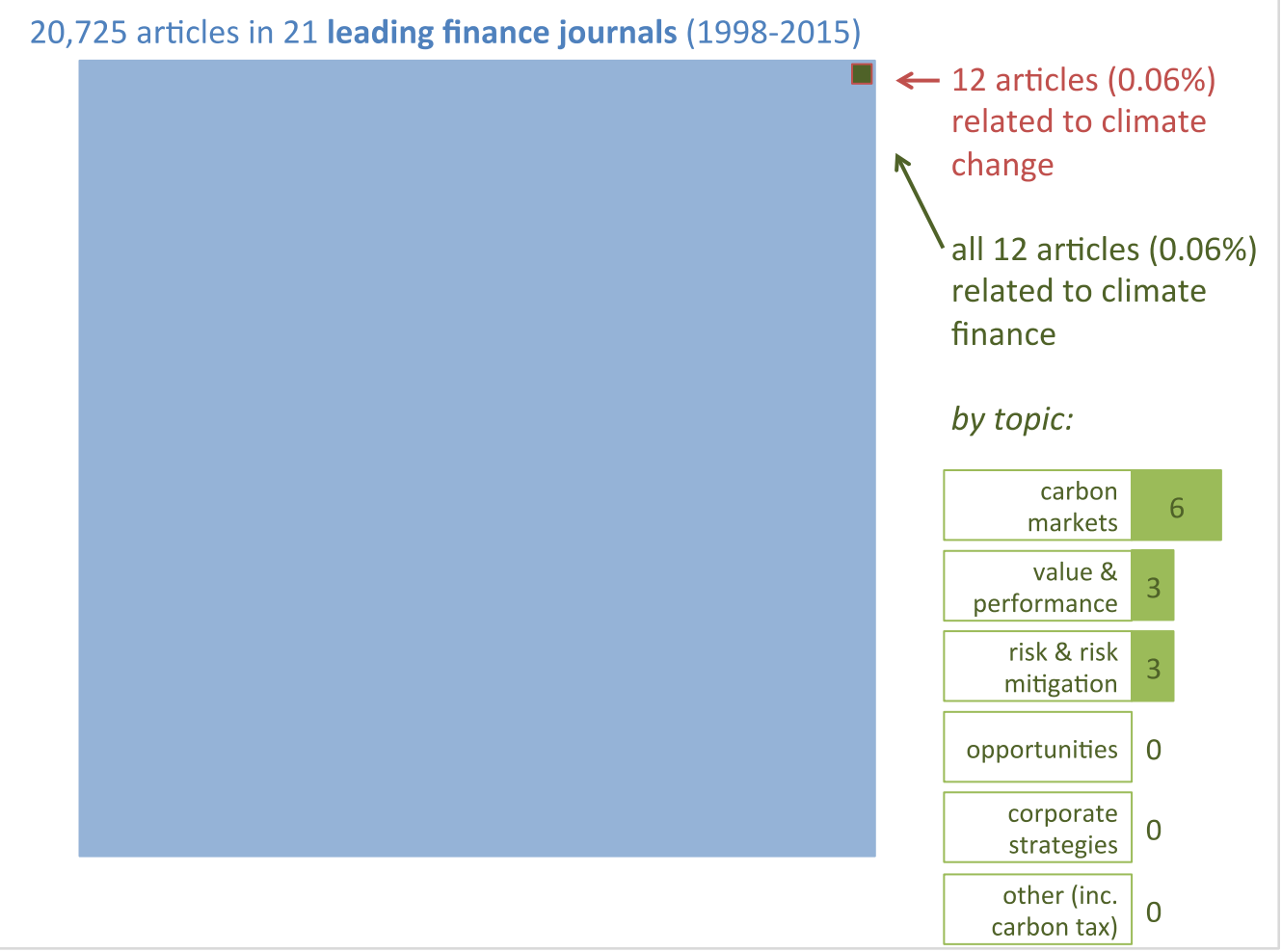

by topic:

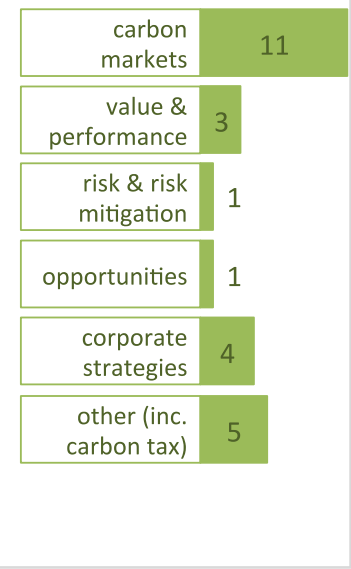


Tables

Table 1. Climate change-related and climate-finance related articles in 21 leading finance journals (Jan 1998-Jun 2015).

\begin{tabular}{|c|c|c|c|c|c|c|c|c|c|c|c|}
\hline \multicolumn{2}{|l|}{ All data for January 1998 - June 2015} & \multicolumn{2}{|c|}{ Climate change-related } & \multicolumn{2}{|c|}{ Climate finance-related } & \multicolumn{6}{|c|}{ Coding of climate finance-related articles } \\
\hline Journals ordered by ranking & $\begin{array}{r}\text { total \# of } \\
\text { articles } \\
\end{array}$ & $\begin{array}{r}\text { \# of climate } \\
\text { change- } \\
\text { related } \\
\text { articles }\end{array}$ & $\begin{array}{r}\text { climate } \\
\text { change- } \\
\text { related as } \\
\% \text { of all } \\
\text { articles }\end{array}$ & $\begin{array}{r}\text { \# of climate } \\
\text { finance- } \\
\text { related } \\
\text { articles } \\
\end{array}$ & $\begin{array}{r}\text { climate } \\
\text { finance- } \\
\text { related as } \\
\% \text { of all } \\
\text { articles }\end{array}$ & 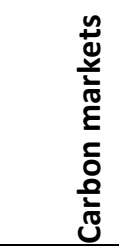 & 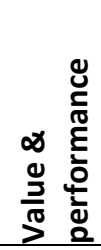 & 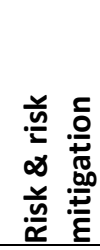 & 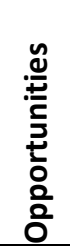 & 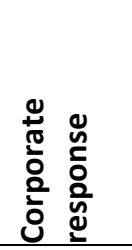 & \begin{tabular}{l}
$\grave{ \pm}$ \\
\multirow{5}{0}{}
\end{tabular} \\
\hline Journal of Finance $*$ & 1412 & 0 & $0.00 \%$ & 0 & $0.00 \%$ & 0 & 0 & 0 & 0 & 0 & 0 \\
\hline Journal of Financial Economics * & 1588 & 0 & $0.00 \%$ & 0 & $0.00 \%$ & 0 & 0 & 0 & 0 & 0 & 0 \\
\hline Review of Financial Studies * & 1202 & 0 & $0.00 \%$ & 0 & $0.00 \%$ & 0 & 0 & 0 & 0 & 0 & 0 \\
\hline Journal of Financial and Quantitative Analysis & 725 & 0 & $0.00 \%$ & 0 & $0.00 \%$ & 0 & 0 & 0 & 0 & 0 & 0 \\
\hline Journal of Money, Credit and Banking & 1246 & 0 & $0.00 \%$ & 0 & $0.00 \%$ & 0 & 0 & 0 & 0 & 0 & 0 \\
\hline Journal of Banking and Finance & 3329 & 4 & $0.12 \%$ & 4 & $0.12 \%$ & 3 & 1 & 0 & 0 & 0 & 0 \\
\hline Mathematical Finance & 514 & 0 & $0.00 \%$ & 0 & $0.00 \%$ & 0 & 0 & 0 & 0 & 0 & 0 \\
\hline Journal of Financial Intermediation & 398 & 0 & $0.00 \%$ & 0 & $0.00 \%$ & 0 & 0 & 0 & 0 & 0 & 0 \\
\hline Journal of Corporate Finance & 864 & 0 & $0.00 \%$ & 0 & $0.00 \%$ & 0 & 0 & 0 & 0 & 0 & 0 \\
\hline Financial Management & 502 & 0 & $0.00 \%$ & 0 & $0.00 \%$ & 0 & 0 & 0 & 0 & 0 & 0 \\
\hline Journal of Empirical Finance & 767 & 1 & $0.13 \%$ & 1 & $0.13 \%$ & 1 & 0 & 0 & 0 & 0 & 0 \\
\hline Journal of International Money and Finance & 1331 & 1 & $0.08 \%$ & 1 & $0.08 \%$ & 1 & 0 & 0 & 0 & 0 & 0 \\
\hline Journal of Financial Markets & 370 & 1 & $0.27 \%$ & 1 & $0.27 \%$ & 1 & 0 & 0 & 0 & 0 & 0 \\
\hline Financial Analysts Journal & 853 & 1 & $0.12 \%$ & 1 & $0.12 \%$ & 0 & 1 & 0 & 0 & 0 & 0 \\
\hline Review of Finance & 433 & 0 & $0.00 \%$ & 0 & $0.00 \%$ & 0 & 0 & 0 & 0 & 0 & 0 \\
\hline Journal of Risk and Insurance & 617 & 2 & $0.32 \%$ & 2 & $0.32 \%$ & 0 & 0 & 2 & 0 & 0 & 0 \\
\hline Quantitative Finance & 1300 & 0 & $0.00 \%$ & 0 & $0.00 \%$ & 0 & 0 & 0 & 0 & 0 & 0 \\
\hline Journal of Financial Research & 477 & 0 & $0.00 \%$ & 0 & $0.00 \%$ & 0 & 0 & 0 & 0 & 0 & 0 \\
\hline Journal of Portfolio Management & 886 & 1 & $0.11 \%$ & 1 & $0.11 \%$ & 0 & 1 & 0 & 0 & 0 & 0 \\
\hline Journal of Business Finance and Accounting & 990 & 0 & $0.00 \%$ & 0 & $0.00 \%$ & 0 & 0 & 0 & 0 & 0 & 0 \\
\hline Journal of Futures Markets & 927 & 1 & $0.11 \%$ & 1 & $0.11 \%$ & 0 & 0 & 1 & 0 & 0 & 0 \\
\hline ALL 21 LEADING FINANCE JOURNALS & 20725 & 12 & $0.06 \%$ & 12 & $0.06 \%$ & 6 & 3 & 3 & 0 & 0 & 0 \\
\hline
\end{tabular}

* Also included in the sample of elite business journals 
Table 2. Climate change-related and climate-finance related articles in 29 elite business journals (Jan 1998-Jun 2015).

\begin{tabular}{|c|c|c|c|c|c|c|c|c|c|c|c|c|}
\hline \multicolumn{3}{|c|}{ All data for January 1998 - June 2015} & \multicolumn{2}{|c|}{ Climate change-related } & \multicolumn{2}{|c|}{ Climate finance-related } & \multicolumn{6}{|c|}{ Coding of climate finance-related articles } \\
\hline \multicolumn{2}{|c|}{ Journals ordered by field and then ranking } & $\begin{array}{r}\text { total \# } \\
\text { of } \\
\text { articles }\end{array}$ & $\begin{array}{r}\text { \# of climate } \\
\text { change- } \\
\text { related } \\
\text { articles }\end{array}$ & $\begin{array}{r}\begin{array}{r}\text { climate } \\
\text { change- }\end{array} \\
\text { related as \% } \\
\text { of all articles }\end{array}$ & $\begin{array}{r}\text { \# of climate } \\
\text { finance- } \\
\text { related } \\
\text { articles }\end{array}$ & $\begin{array}{r}\text { climate } \\
\text { finance- } \\
\text { related as \% } \\
\text { of all articles }\end{array}$ & 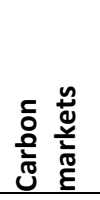 & 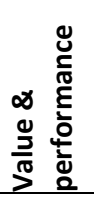 & 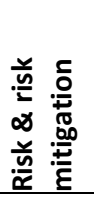 & 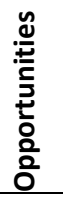 & 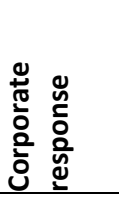 & $\begin{array}{l}\grave{\Phi} \\
\stackrel{ \pm}{ \pm} \\
\text { ठ }\end{array}$ \\
\hline \multirow{4}{*}{ ACC } & Accounting Review & 905 & 1 & $0.11 \%$ & 1 & $0.11 \%$ & 0 & 1 & 0 & 0 & 0 & 0 \\
\hline & Accounting, Organizations and Society & 660 & 6 & $0.91 \%$ & 6 & $0.91 \%$ & 3 & 0 & 0 & 0 & 3 & 0 \\
\hline & Journal of Accounting and Economics & 577 & 0 & $0.00 \%$ & 0 & $0.00 \%$ & 0 & 0 & 0 & 0 & 0 & 0 \\
\hline & Journal of Accounting Research & 640 & 0 & $0.00 \%$ & 0 & $0.00 \%$ & 0 & 0 & 0 & 0 & 0 & 0 \\
\hline \multirow{6}{*}{ ECO } & American Economic Review & 3505 & 36 & $1.03 \%$ & 9 & $0.26 \%$ & 4 & 2 & 0 & 0 & 0 & 3 \\
\hline & Annals of Statistics & 1677 & 2 & $0.12 \%$ & 0 & $0.00 \%$ & 0 & 0 & 0 & 0 & 0 & 0 \\
\hline & Econometrica & 1077 & 1 & $0.09 \%$ & 1 & $0.09 \%$ & 0 & 0 & 0 & 0 & 0 & 1 \\
\hline & Journal of Political Economy & 694 & 1 & $0.14 \%$ & 0 & $0.00 \%$ & 0 & 0 & 0 & 0 & 0 & 0 \\
\hline & Quarterly Journal of Economics & 718 & 1 & $0.14 \%$ & 0 & $0.00 \%$ & 0 & 0 & 0 & 0 & 0 & 0 \\
\hline & Review of Economic Studies & 777 & 1 & $0.13 \%$ & 0 & $0.00 \%$ & 0 & 0 & 0 & 0 & 0 & 0 \\
\hline \multirow{4}{*}{ GMN } & Academy of Management Journal & 1179 & 2 & $0.17 \%$ & 0 & $0.00 \%$ & 0 & 0 & 0 & 0 & 0 & 0 \\
\hline & Academy of Management Review & 732 & 0 & $0.00 \%$ & 0 & $0.00 \%$ & 0 & 0 & 0 & 0 & 0 & 0 \\
\hline & Administrative Science Quarterly & 366 & 0 & $0.00 \%$ & 0 & $0.00 \%$ & 0 & 0 & 0 & 0 & 0 & 0 \\
\hline & Journal of Management & 903 & 0 & $0.00 \%$ & 0 & $0.00 \%$ & 0 & 0 & 0 & 0 & 0 & 0 \\
\hline \multirow{3}{*}{ FIN } & Journal of Finance & 1412 & 0 & $0.00 \%$ & 0 & $0.00 \%$ & 0 & 0 & 0 & 0 & 0 & 0 \\
\hline & Journal of Financial Economics & 1588 & 0 & $0.00 \%$ & 0 & $0.00 \%$ & 0 & 0 & 0 & 0 & 0 & 0 \\
\hline & Review of Financial Studies & 1202 & 0 & $0.00 \%$ & 0 & $0.00 \%$ & 0 & 0 & 0 & 0 & 0 & 0 \\
\hline \multirow{5}{*}{ MKT } & Journal of Consumer Psychology & 788 & 0 & $0.00 \%$ & 0 & $0.00 \%$ & 0 & 0 & 0 & 0 & 0 & 0 \\
\hline & Journal of Consumer Research & 1092 & 0 & $0.00 \%$ & 0 & $0.00 \%$ & 0 & 0 & 0 & 0 & 0 & 0 \\
\hline & Journal of Marketing & 761 & 0 & $0.00 \%$ & 0 & $0.00 \%$ & 0 & 0 & 0 & 0 & 0 & 0 \\
\hline & Journal of Marketing Research & 969 & 0 & $0.00 \%$ & 0 & $0.00 \%$ & 0 & 0 & 0 & 0 & 0 & 0 \\
\hline & Marketing Science & 927 & 0 & $0.00 \%$ & 0 & $0.00 \%$ & 0 & 0 & 0 & 0 & 0 & 0 \\
\hline \multirow{3}{*}{ ORM } & Journal of Operations Management & 753 & 0 & $0.00 \%$ & 0 & $0.00 \%$ & 0 & 0 & 0 & 0 & 0 & 0 \\
\hline & Management Science & 2415 & 8 & $0.33 \%$ & 2 & $0.08 \%$ & 1 & 0 & 0 & 1 & 0 & 0 \\
\hline & Operations Research & 1673 & 5 & $0.30 \%$ & 4 & $0.24 \%$ & 3 & 0 & 0 & 0 & 0 & 1 \\
\hline \multirow{4}{*}{ OTH } & Journal of International Business Studies & 992 & 3 & $0.30 \%$ & 1 & $0.10 \%$ & 0 & 0 & 1 & 0 & 0 & 0 \\
\hline & Information Systems Research & 626 & 0 & $0.00 \%$ & 0 & $0.00 \%$ & 0 & 0 & 0 & 0 & 0 & 0 \\
\hline & MIS Quarterly: Management Information Systems & 653 & 2 & $0.31 \%$ & 0 & $0.00 \%$ & 0 & 0 & 0 & 0 & 0 & 0 \\
\hline & Organization Science & 1097 & 5 & $0.46 \%$ & 1 & $0.09 \%$ & 0 & 0 & 0 & 0 & 1 & 0 \\
\hline \multicolumn{2}{|c|}{ ALL 29 ELITE BUSINESS JOURNALS } & 31351 & 74 & $0.24 \%$ & 25 & $0.08 \%$ & 11 & 3 & 1 & 1 & 4 & 5 \\
\hline
\end{tabular}

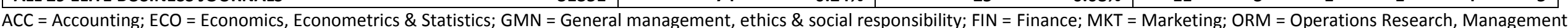
Science, Operations \& Tech Management; OTH = Other, including Information Management, International Business \& Area Studies, Organisation Studies 


\section{Appendices}

Table A1. Coverage of Climate Change-Related Articles in Leading Finance and Elite Business Journals during 1998-2015 and 2012-2015.

\begin{tabular}{|c|c|c|c|c|c|c|c|c|c|}
\hline & $\begin{array}{r}\text { \# of } \\
\text { journals }\end{array}$ & $\begin{array}{r}\text { total \# of } \\
\text { articles } \\
\end{array}$ & $\begin{array}{c}\text { \# of } \\
\text { climate } \\
\text { change- } \\
\text { related } \\
\text { articles } \\
\end{array}$ & $\begin{array}{r}\text { climate } \\
\text { change- } \\
\text { related as } \\
\% \text { of all } \\
\text { articles } \\
\end{array}$ & $\begin{array}{r}\text { \% of journals } \\
\text { with }>0 \\
\text { climate } \\
\text { change- } \\
\text { related } \\
\text { articles } \\
\end{array}$ & $\begin{array}{r}\text { average \# of } \\
\text { climate } \\
\text { change- } \\
\text { related } \\
\text { articles per } \\
\text { journal } \\
\end{array}$ & $\begin{array}{r}\text { max \# of } \\
\text { climate } \\
\text { change- } \\
\text { related } \\
\text { articles per } \\
\text { journal } \\
\end{array}$ & $\begin{array}{r}\text { min \# of } \\
\text { climate } \\
\text { change- } \\
\text { related } \\
\text { articles per } \\
\text { journal } \\
\end{array}$ & $\begin{array}{r}\text { s.d. of } \\
\text { climate } \\
\text { change- } \\
\text { related } \\
\text { articles per } \\
\text { journal }\end{array}$ \\
\hline \multicolumn{10}{|c|}{ January 1998 - June 2015 (16.5 year period) } \\
\hline ALL LEADING FINANCE JOURNALS & 21 & 20725 & 12 & $0.06 \%$ & $38 \%$ & 0.57 & 4 & 0 & 0.95 \\
\hline ALL ELITE BUSINESS JOURNALS & 29 & 31351 & 74 & $0.24 \%$ & & & & & \\
\hline \multicolumn{10}{|l|}{ of which } \\
\hline ACCOUNTING & 4 & 2781 & 7 & $0.25 \%$ & $50 \%$ & 1.75 & 6 & 0 & 2.49 \\
\hline ECONOMICS, ECONOMETRICS \& STATISTICS & 6 & 8446 & 42 & $0.50 \%$ & $100 \%$ & 7.00 & 36 & 1 & 12.97 \\
\hline GENERAL MANAGEMENT, ETHICS \& SOCIAL RESPONSIBILITY & 4 & 3179 & 2 & $0.06 \%$ & $25 \%$ & 0.50 & 2 & 0 & 0.87 \\
\hline FINANCE & 3 & 4201 & 0 & $0.00 \%$ & $0 \%$ & 0.00 & 0 & 0 & 0.00 \\
\hline MARKETING & 5 & 4536 & 0 & $0.00 \%$ & $0 \%$ & 0.00 & 0 & 0 & 0.00 \\
\hline $\begin{array}{l}\text { OPERATIONS RESEARCH, MANAGEMENT SCIENCE, } \\
\text { OPERATIONS \& TECH. MANAGEMENT } \\
\text { OTHER (INFORMATION MANAGEMENT, INTERNATIONAL }\end{array}$ & 3 & 4841 & 13 & $0.27 \%$ & $67 \%$ & 4.33 & 8 & 0 & 3.30 \\
\hline BUSINESS \& AREA STUDIES, ORGANISATION STUDIES) & 4 & 3368 & 10 & $0.30 \%$ & $75 \%$ & 2.50 & 5 & 0 & 1.80 \\
\hline \multicolumn{10}{|c|}{ January 2012 - June 2015 (3.5 year period) } \\
\hline ALL LEADING FINANCE JOURNALS & 21 & 5823 & 6 & $0.10 \%$ & $24 \%$ & 0.29 & 2 & 0 & 0.55 \\
\hline ALL ELITE BUSINESS JOURNALS & 29 & 7379 & 36 & $0.49 \%$ & & & & & \\
\hline \multicolumn{10}{|l|}{ of which } \\
\hline ACCOUNTING & 4 & 675 & 1 & $0.15 \%$ & $25 \%$ & 0.25 & 1 & 0 & 0.43 \\
\hline ECONOMICS, ECONOMETRICS \& STATISTICS & 6 & 1854 & 19 & $1.02 \%$ & $83 \%$ & 3.17 & 15 & 0 & 5.30 \\
\hline GENERAL MANAGEMENT, ETHICS \& SOCIAL RESPONSIBILITY & 4 & 721 & 2 & $0.28 \%$ & $25 \%$ & 0.50 & 2 & 0 & 0.87 \\
\hline FINANCE & 3 & 1028 & 0 & $0.00 \%$ & $0 \%$ & 0.00 & 0 & 0 & 0.00 \\
\hline MARKETING & 5 & 1107 & 0 & $0.00 \%$ & $0 \%$ & 0.00 & 0 & 0 & 0.00 \\
\hline $\begin{array}{l}\text { OPERATIONS RESEARCH, MANAGEMENT SCIENCE, } \\
\text { OPERATIONS \& TECH. MANAGEMENT } \\
\text { OTHER (INFORMATION MANAGEMENT, INTERNATIONAL }\end{array}$ & 3 & 1064 & 7 & $0.66 \%$ & $67 \%$ & 2.33 & 5 & 0 & 2.05 \\
\hline BUSINESS \& AREA STUDIES, ORGANISATION STUDIES) & 4 & 931 & 7 & $0.75 \%$ & $75 \%$ & 1.75 & 5 & 0 & 1.92 \\
\hline
\end{tabular}


Table A2. Domicile of Editor(s) of Leading Finance Journals, and Climate Change-

Related Coverage during 1998-2015 and 2012-2015.

\begin{tabular}{|c|c|c|c|c|c|c|c|}
\hline \multirow[b]{2}{*}{ Journal } & \multirow[b]{2}{*}{$\begin{array}{c}\text { Editor(s) } \\
\text { Domicile } \\
*\end{array}$} & \multicolumn{3}{|c|}{ January 1998 - June 2015} & \multicolumn{3}{|c|}{ January 2012 - June 2015} \\
\hline & & $\begin{array}{r}\text { \# of } \\
\text { climate- } \\
\text { change } \\
\text { related } \\
\text { articles }\end{array}$ & $\begin{array}{r}\text { total \# } \\
\text { of } \\
\text { articles } \\
\end{array}$ & $\begin{array}{r}\text { climate } \\
\text { change- } \\
\text { related as } \\
\% \text { of all } \\
\text { articles } \\
\end{array}$ & $\begin{array}{r}\text { \# of } \\
\text { climate- } \\
\text { change } \\
\text { related } \\
\text { articles } \\
\end{array}$ & $\begin{array}{r}\text { total \# } \\
\text { of } \\
\text { articles } \\
\end{array}$ & $\begin{array}{r}\text { climate } \\
\text { change- } \\
\text { related as } \\
\% \text { of all } \\
\text { articles } \\
\end{array}$ \\
\hline Journal of Finance & US & 0 & 1412 & $0.00 \%$ & 0 & 246 & $0.00 \%$ \\
\hline Journal of Financial Economics & US & 0 & 1588 & $0.00 \%$ & 0 & 461 & $0.00 \%$ \\
\hline Review of Financial Studies & INT & 0 & 1202 & $0.00 \%$ & 0 & 322 & $0.00 \%$ \\
\hline J. of Financial and Quantitative Analysis & US & 0 & 725 & $0.00 \%$ & 0 & 194 & $0.00 \%$ \\
\hline Journal of Money, Credit and Banking & US & 0 & 1246 & $0.00 \%$ & 0 & 304 & $0.00 \%$ \\
\hline Journal of Banking and Finance & INT & 4 & 3329 & $0.12 \%$ & 2 & 1181 & $0.17 \%$ \\
\hline Mathematical Finance & US & 0 & 514 & $0.00 \%$ & 0 & 140 & $0.00 \%$ \\
\hline Journal of Financial Intermediation & US & 0 & 398 & $0.00 \%$ & 0 & 108 & $0.00 \%$ \\
\hline Journal of Corporate Finance & US & 0 & 864 & $0.00 \%$ & 0 & 354 & $0.00 \%$ \\
\hline Financial Management & INT & 0 & 502 & $0.00 \%$ & 0 & 116 & $0.00 \%$ \\
\hline Journal of Empirical Finance & INT & 1 & 767 & $0.13 \%$ & 1 & 270 & $0.37 \%$ \\
\hline J. of International Money and Finance & INT & 1 & 1331 & $0.08 \%$ & 1 & 466 & $0.21 \%$ \\
\hline Journal of Financial Markets & INT & 1 & 370 & $0.27 \%$ & 1 & 111 & $0.90 \%$ \\
\hline Financial Analysts Journal & INT & 1 & 853 & $0.12 \%$ & 0 & 146 & $0.00 \%$ \\
\hline Review of Finance & INT & 0 & 433 & $0.00 \%$ & 0 & 162 & $0.00 \%$ \\
\hline Journal of Risk and Insurance & INT & 2 & 617 & $0.32 \%$ & 1 & 151 & $0.66 \%$ \\
\hline Quantitative Finance & INT & 0 & 1300 & $0.00 \%$ & 0 & 499 & $0.00 \%$ \\
\hline Journal of Financial Research & US & 0 & 477 & $0.00 \%$ & 0 & 80 & $0.00 \%$ \\
\hline Journal of Portfolio Management & INT & 1 & 886 & $0.11 \%$ & 0 & 153 & $0.00 \%$ \\
\hline J. of Business Finance and Accounting & INT & 0 & 990 & $0.00 \%$ & 0 & 160 & $0.00 \%$ \\
\hline Journal of Futures Markets & US & 1 & 927 & $0.11 \%$ & 0 & 205 & $0.00 \%$ \\
\hline \multicolumn{2}{|l|}{ ALL 21 LEADING FINANCE JOURNALS } & 12 & 20725 & $0.06 \%$ & 6 & 5823 & $0.10 \%$ \\
\hline
\end{tabular}

${ }^{*}$ Editors or editorial teams (including co-editors, managing editors, executive editors but excluding associated editors) were coded as "US" if only US-based or "INT" if they included at least one non-US domiciled editor (see text for details). 